平成 14 年度（第 45 回）果汁技術研究発表会

いまなぜ，果実飲料の品質なのか 一安全と安心一

主 催：(社)日本果汁協会果汁技術研究部会

記

日 時: 平成 14 年 9 月 13 日（金） 10 時 16 時 30 分

場 所 : 銀座ガスホール 7F 東京都中央区銀座 7-9-15 順序 :

$10: 10 \sim 11: 50$ 研究発表 5 題

$12: 50 \sim 13: 10$ 技術賞授賞式
$13: 10 \sim 13: 40$ 受賞者講演

$13: 40 \sim 14: 20$ 研究発表 2 題

$14: 20 \sim 15: 55$ 特別講演 2 題

$16: 30 \sim$ 交流会（会費 5000 円）： サッポロビール ライオン銀座 7 丁目店 $6 \mathrm{~F}$

入場料は無料です.

(問い合わせ先)：(社)日本果汁協会

TEL : 03-3275-1031 FAX : 03-3275-1067

\title{
記 事
}

\section{平成 14 年度第 2 回総務委員会議事概要}

日 時: 平成 14 年 5 月 28 日 (火) $14: 00 \sim 15: 50$ 場 所：農水省共済組合南青山会館（東京都港区）

出 席 者: (農林水産省)川口, 山本(委員長)佐々木(委 員)飯野, 大坪, 鈴木, 高村 (事務局)久保

挨拶：佐々木委員長及び農林水産省川口室長から挨 拶が述べられた。
議題：佐々木委員長が議長となって議事を進めた.

（1）事務局報告及び「職員の給与支給について」の報 告があり，了承された.

（2）役員の給与規程及び役員の退職手当規程制定の案 が示され，質疑応答の後了承された。

（3）創立 50 周年記念事業の案が示され，質疑応答の 後了承された。

\begin{tabular}{ll}
\hline 訂 & 正 \\
\hline
\end{tabular}

○第 49 巻第 7 号 $\quad$ p. 465

Fig. 2 綐軸 Flesh firmness の単位
(詔)
\%
(正) $\mathrm{g}$ 